\title{
Marketing strategies for alternative medicine businesses of the municipal head of Villa Guerrero, State of Mexico
}

\section{Estrategias de mercadotecnia para negocios de medicina alternativa de la cabecera municipal de Villa Guerrero, Estado de México}

\author{
MONTES DE OCA-ESTRADA, Anabel Regina $\dagger^{*}$ \\ Tecnológico de Estudios Superiores de Villa Guerrero, México \\ ID $1^{\mathrm{er}}$ Autor: Anabel Regina, Montes de Oca-Estrada / ORC ID: 0000-0003-1586-6440
}

DOI: $10.35429 / J G E .2020 .6 .4 .16 .24$

Received March 17, 2020; Accepted June 15, 2020

\begin{abstract}
The present research aims to propose marketing strategies to support alternative medicine establishments in the municipal head of Villa Guerrero, State of Mexico; through a nonexperimental, cross-sectional, quantitative, and descriptive study. Taking as a technique the survey, applied to 370 people over 18 years of age, resulting in that Alternative Medicine continues to be a common practice in women, more than in men, however, product, price, place and place strategies are proposed. promotion for the characteristics of regular consumers.
\end{abstract}

\section{Alternative medicine, Strategies, Marketing}

\section{Resumen}

La presente investigación tiene como objetivo proponer estrategias de mercadotecnia para apoyar a los establecimientos de medicina alternativa en la cabecera municipal de Villa Guerrero, Estado de México; a través de un estudio de tipo no experimental, transversal, cuantitativo, y descriptivo. Teniendo como técnica la encuesta, aplicada a 370 personas mayores de 18 años, dando como resultado que la Medicina Alternativa sigue siendo una práctica usual en las mujeres, más que en los hombres, no obstante, se proponen estrategias de producto, precio, plaza y promoción para las características de los consumidores asiduos.

\section{Medicina Alternativa, Estrategias, Mercadotecnia}

\footnotetext{
* Correspondence to Author (email: monrestan@yahoo.com.mx)

$\dagger$ Researcher contributing first author.
} 


\section{Introduction}

Alternative medicine for years has taken an important place within the country, and some parts of the world, starting in the 90s, there has been a resurgence of the use of alternative medicines (Blanco, 2017).

Traditional medicine services present a growing demand, since it is used as an alternative to maintain health, prevent and treat diseases, especially in rural areas (GallegosZurita and Gallegos-Z, 2017).

In addition, constant use can serve (based on empirical experiences) for the treatment of different diseases such as: endocrine, respiratory, digestive, nervous system, cancer, among others; that over the years have come to manifest in people who have resorted to the use of various techniques or treatments of alternative medicine (Documentary: Traditional medicine, dose of health and identity, 2014).

With the label of alternative, it is encompassed from totally structured views of health with prevention, diagnosis and therapeutic criteria, such as Chinese medicine and Ayurveda, along with options more focused on treatment such as neural therapy and homeopathy and even chiropractic, and with more healing techniques, such as reiki, music therapy, flower essences, magnetic fields, naturopathy, energy healing, ozone therapy, dowsing and divine healing (Blanco, 2017).

In the municipal capital of Villa Guerrero, State of Mexico, there are establishments that offer alternative medicine products, which can be beneficial for the population in terms of economy and confidence, covering the needs of well-being and health, since people resort to these products with the ideology of healing or improving the conditions they have; However, it is intended, with this research, to propose marketing strategies that help these establishments, covering product, place, price and promotion strategies (marketing mix) basically, as a start to consider these places, as businesses that offer products for customers with specific characteristics and needs.

\section{Literature Review}

According to Dr. José Rodríguez Domínguez (1998), he mentions that until a few years ago, numerous practices with curative intentions were considered as spaces of eccentricity, quackery, charlatanism, etc., and immediately disqualified as non-rational, non-serious practices or illegal. However, since the eighties, they have been consistently gaining respectability, acquiring a place within the arts of healing and healing. This appears to be due to its positive effects in the treatment of patients in whom conventional allopathic medicine has failed.

Rodríguez (Alternative Medicine in the medical curriculum, 1998) also mentions that since the eighties, the Mexican Institute of Social Security (IMSS) established a program for the study and development of Mexican herbalism. Therefore, there is a need to define what, from the perspective of the World Health Organization, traditional medicine is the entire set of knowledge, skills and practices based on theories, beliefs and indigenous experiences of different cultures, be they or unexplained, used for the maintenance of health, as well as for the prevention, diagnosis, improvement or treatment of physical or mental illnesses (Zhang, 2019).

On the other hand, the terms "complementary medicine" and "alternative medicine" are used interchangeably together with "traditional medicine" in some countries. They refer to a broad set of health care practices that are not part of the tradition of the country and are not integrated into the main health system (Zhang, 2019).

Also, the term natural, complementary or alternative medicine broadly designates the methods and practices used instead, or as a complement, to conventional medical treatments to cure or alleviate diseases (Pinedo, 2018). Refers to low- or no-risk treatments that are used in place of conventional (standard) treatments. Likewise, if an alternative treatment is used together with medicine or conventional therapy, the alternative treatment will be considered as complementary therapy (MedlinePlus, 2020). 
Alternative Medicine and Alternative and Complementary Therapies (AM and TAC) make up a medical system and related therapies, recognized in many countries of the world, not only by legislators and administrators of the health sector, but by users because they constitute an option to attend to their needs (SENA, 2006). There are those who believe that alternative medicine may be the solution to the increasing cost of Western medicine, which is more critical in poor countries such as Mexico (Peña and Paco, 2007).

In a study carried out, called The use of alternative and complementary therapies in the Mexican population with depressive and anxiety disorders: results of a survey in Mexico City, it was found that those who resorted to home remedies sought to alleviate nerves and anxiety. insomnia. The main reason why they did some physical activity or attended healing practices adapted from other countries was: to relax or relieve stress.

The interviewees used vitamins or food supplements to treat the sensation of weakness, lack of energy and strength, all these concepts underlying the idea of obtaining an improvement in their state or condition (Berenzon Gorn, Alanís Navarro, \& Saavedra Solano, 2009) .

Regarding the legal framework, Manuel Díaz (2013) refers to the General Directorate for Health Planning and Development, through the creation in 2002 of the Directorate for Traditional Medicine and Intercultural Development, which aims to promote a model intercultural to position in the offer of institutional services, a vision in accordance with the expectations of society and indigenous peoples, through an innovative and expanded vision regarding the issue of interculturality in health, in order to influence the institutional resolution of the problems on these issues and the definition of a policy regarding traditional Mexican medicine, the so-called Complementary Medicines, present in the preferences of society and the offer of services (Perspectives of alternative and / or complementary medicines at the Universidad del Valle de Atemajac (UNIVA), Campus Zapopan, Jalisco, 2013).
It is there, where the meaning of this research is generated, since Alternative Medicine has been considered from a medical perspective, however, the administrative perspective is also generated, considering as micro-businesses the establishments that offer these products that have become a necessity for consumers, with very specific characteristics.

In Mexico there are about 50,000 establishments that sell herbal products, food supplements and naturopathic medicine and these very conservatively enter an average of 100,000 pesos per year, there is talk of a sector with a spill generated by no less than 5,000 million pesos (Ramírez, 2018 ). It is a first estimate made by the National Federation of the Herbal Industry and Alternative, Traditional and Naturist Medicine (FNIHMATN).

Therefore, it will also be necessary to consider marketing (also known as marketing anglicism) that, like any other micro-business, needs for its subsistence and development. Considering marketing as the business process through which the consumer obtains well-being through the exchange of products of value (Rattinger, 2018). Likewise, it is a set of activities that are carried out to determine what the needs and demands of a public or market are, with the aim of satisfying them through products or services (Economic Encyclopedia, 2018). Marketing does not create needs, it only discovers, structures and satisfies them (Sangri, 2014).

Consequently, this research does not seek to create the need to consume Alternative Medicine, but there are already people who know and need it, therefore, it seeks to generate marketing strategies that the establishments that sell these products, located in the Municipal Headquarters of Villa Guerrero, State of Mexico can, at a certain time, put into practice, as a support to the development of these, and of the same locality.

Marketing strategies or marketing strategies refer to the set of actions that have the objective of increasing sales and achieving a sustainable competitive advantage. The fundamental purpose is to identify and communicate the benefits that the business offers to the target market (Galeano, 2019). 
A business unit hopes to achieve its marketing objectives by: 1) selecting the target market it wants to reach, 2) defining the positioning it will try to achieve in the minds of the target customers, 3) choosing the combination or mix of marketing (product, place, price and promotion) with which it will try to satisfy the needs or desires of the target market and 4) the determination of the levels of marketing expenses (Ferrell and Hartline, 2012). The marketing mix is defined as the set of tools used to implement the previously created marketing strategy, in order to reach the company's target audience using these four variables: product, price, communication and distribution, which are called the 4P's by their Anglo-Saxon denomination (Product, Price, Promotion and Place) (Martínez, Ruiz, and Escriva, 2014).

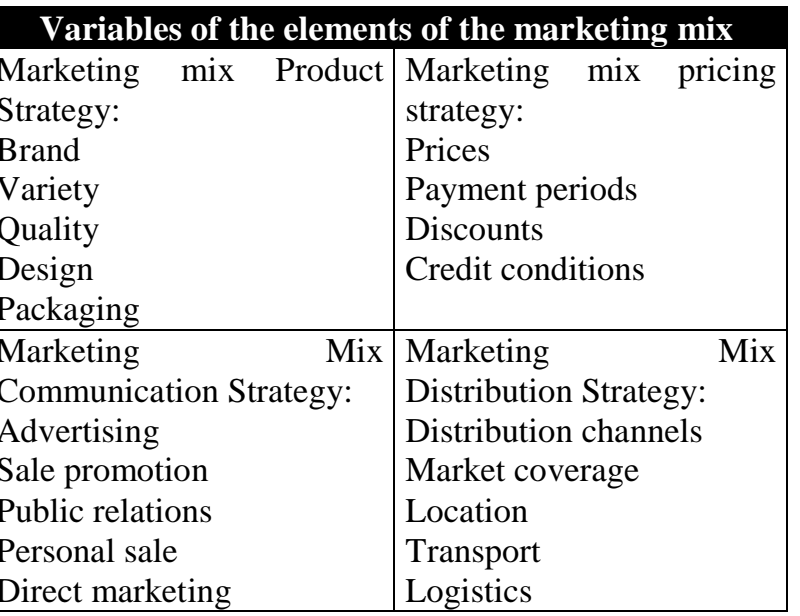

Table 1 Variables of the elements of the marketing mix Source: (Romero, 2019)

Note. This Table shows the basic variables that are considered for the elements of the marketing mix mainly.

\section{Methodology}

This research is non-experimental, because it is carried out without the deliberate manipulation of variables and in which the phenomena are only observed in their natural environment and then analyzed (Hernández, Fernández, \& Baptista, 2010); in this case, the characteristics of the people are studied, with respect to the use and consumption of Alternative Medicine, to later propose marketing strategies. Transversal, since information about the object of study is obtained only once at a given time, which was in October 2019, people belonging to the Municipal Head of Villa Guerrero were identified, and the survey was applied to them.
Descriptive because facts, situations, features, characteristics of an object of study are shown, narrated, outlined or identified, or products, models, prototypes, guides, etc. are designed. But no explanations, reasons or explanations of the phenomena, situations are given (Bernal, 2010). Consequently, general marketing strategies were designed for Alternative Medicine establishments (Santana, García, Millán, \& Miranda, 2020)

The study population was considered by those people belonging to the Municipal Head of Villa Guerrero, State of Mexico; older than 18 years, considering a simple random sampling, where $47 \%$ and $53 \%$ corresponding to the percentages of women and men respectively, of legal age, with the same probability of consuming Alternative Medicine were taken; As a result of the sample, a total of 370 people were obtained, who answered a questionnaire whose structure includes data on sex, age, occupation, academic level, factors that were considered in relation to whether they use Alternative Medicine.

In addition to 19 multiple-choice questions; which, later, were analyzed through the Statistical Program for Social Sciences (SPSS, for its acronym in English) version 22, with which descriptive statistics (percentages and frequencies) were obtained.

\section{Results}

The questionnaires were applied in the center of the Municipal Head of Villa Guerrero, in the month of October 2019, to 370 people, in which the following data were found: they are mostly women $(61.6 \%)$, the age range is between 18 and 27 years old mainly $(39.7 \%)$, the most prevalent academic level is secondary school $(39.7 \%)$ and the activity they mainly perform is a trade $(49.5 \%)$. (See Table 2$)$ 


\begin{tabular}{|l|r|}
\hline \multicolumn{1}{|c|}{ Features } & \multicolumn{1}{c|}{ (\%) } \\
\hline Gender & $142(38.4)$ \\
\hline Man & $228(61.6)$ \\
\hline Woman & \\
\hline Age & $1(0.3)$ \\
\hline Unanswered & $147(39.7)$ \\
\hline $18-27$ & $105(28.4)$ \\
\hline $28-37$ & $64(17.3)$ \\
\hline $38-47$ & $39(10.5)$ \\
\hline $48-57$ & $14(3.8)$ \\
\hline 58 or more & \\
\hline Academic level & $3(0.8)$ \\
\hline Unanswered & $65(17.6)$ \\
\hline Primary & $117(31.6)$ \\
\hline High school & $107(28.9)$ \\
\hline High school & $77(20.8)$ \\
\hline Bachelor's degree & $1(0.3)$ \\
\hline Other & \\
\hline Occupation & $1(0.3)$ \\
\hline Unanswered & $40(10.8)$ \\
\hline student & $183(49.5)$ \\
\hline Job & $102(27.6)$ \\
\hline Home & $30(8.1)$ \\
\hline Profession & $14(3.8)$ \\
\hline Other &
\end{tabular}

Table 2 Main features

Source: Adapted from SPSS version 22

\begin{tabular}{|c|c|c|c|c|c|}
\hline & \multicolumn{2}{|c|}{$\begin{array}{c}\text { Do you use alternative } \\
\text { medicine? }\end{array}$} & \multirow[t]{2}{*}{ Total } \\
\hline & & & Yes & No & \\
\hline \multirow{4}{*}{ Gender } & \multirow{2}{*}{ Male } & Count & 112 & 30 & 142 \\
\hline & & $\%$ of the total & $30.3 \%$ & $8.1 \%$ & $38.4 \%$ \\
\hline & \multirow{2}{*}{ Female } & Count & 188 & 40 & 228 \\
\hline & & $\%$ of the total & $50.8 \%$ & $10.8 \%$ & $61.6 \%$ \\
\hline \multirow{2}{*}{\multicolumn{2}{|c|}{ Total }} & Count & 300 & 70 & 370 \\
\hline & & $\%$ of the total & $81.1 \%$ & $18.9 \%$ & $100.0 \%$ \\
\hline
\end{tabular}

Table 3 Relationship between the use of Alternative Medicine and Sex. Adapted from SPSS version 22

Note: The results showed that $81.1 \%$ of the population use Alternative Medicine, of which women are the ones who use it the most with a frequency of $188(50.8 \%)$.

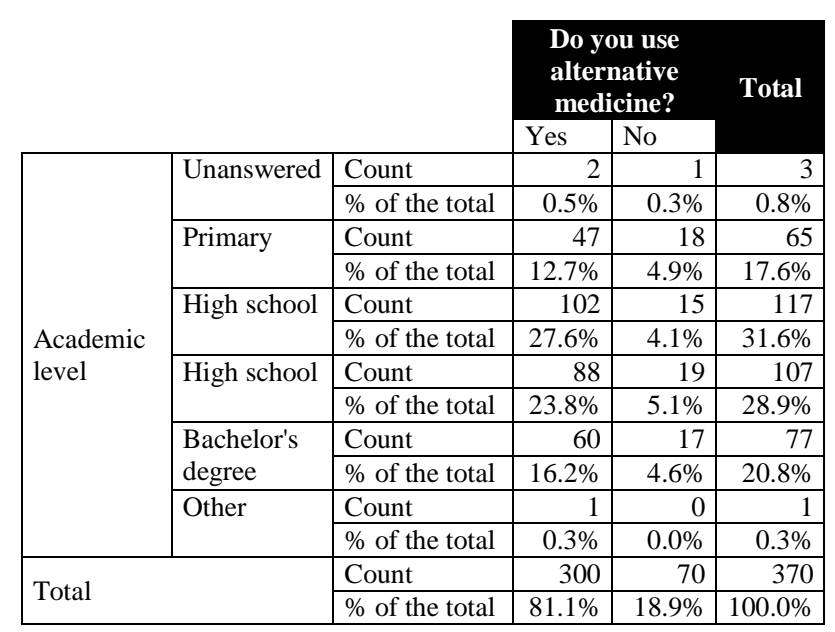

Table 4 Alternative Medicine use relationship with academic level. Adapted from SPSS version 22
Note: The highest academic level is secondary, obtaining a total of 117 frequency, of which $102(27.6 \%)$ mention that, if they use Alternative Medicine, followed by high school 88 (23.8\%) and Bachelor's degree 60 (16.2\%).

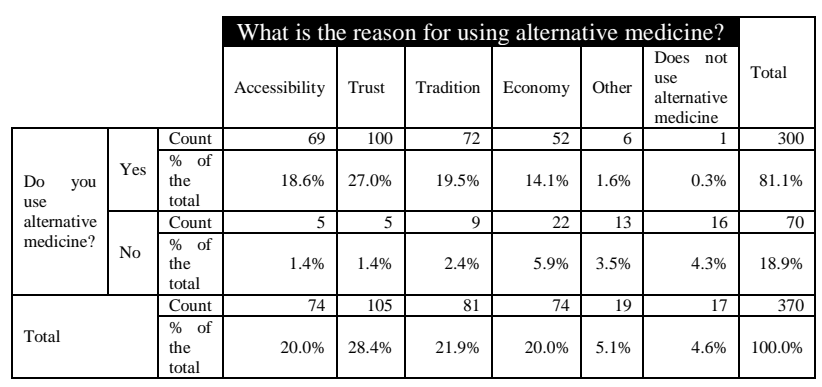

Table 5 Relation of use of Alternative Medicine with reason. Adapted from SPSS version 22

Note: The main reason for using Alternative Medicine is trust, which obtained $28.4 \%$, adding both those surveyed who use it and those who do not, that perhaps, because at some point in their life they have resorted to it, although not be frequently.

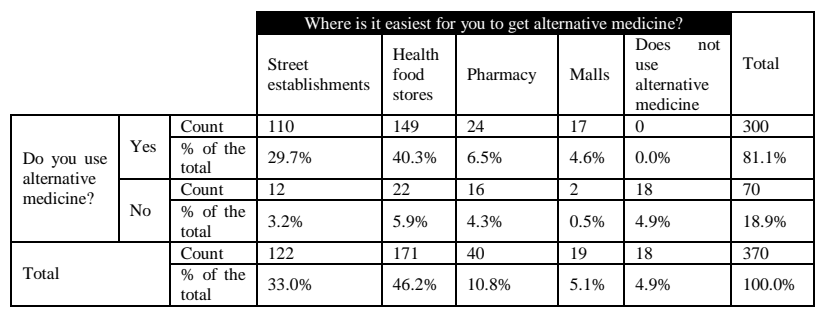

Table 6 Relationship of use of Alternative Medicine with place of acquisition. Adapted from SPSS version 22

Note: Health food stores obtained a frequency of $149(40.3 \%)$, which is a beneficial result for the research, because it is to this type of places, those that are in the Municipal Head of Villa Guerrero, and it is to whom the marketing strategies that are considered.

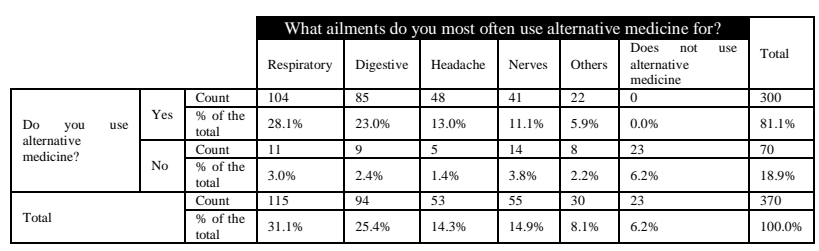

Table 7 Relationship of use of Alternative Medicine and discomforts. Adapted from SPSS version 22

Note: People who use Alternative Medicine use it mainly to treat respiratory ailments, which obtained a frequency of 104 (28.1\%), as well as for digestives with a frequency of $85(23.0 \%)$. 


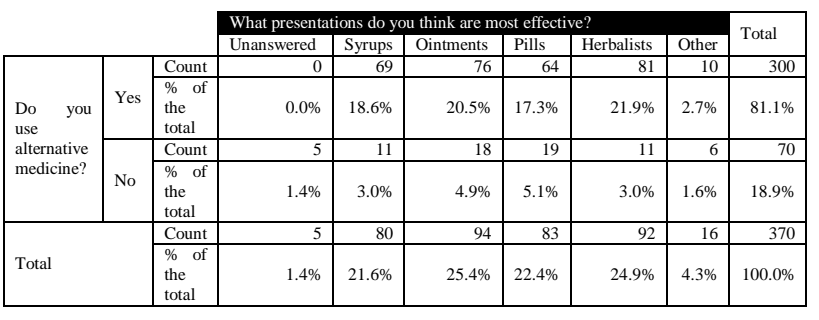

Table 8 Relationship of use of Alternative Medicine with presentations used. Adapted from SPSS version 22.

Note: People prefer to use the herbal and ointment presentations, obtaining a frequency of $81(21.9 \%)$ and $76(20.5 \%)$ respectively, so it can be considered for product strategies.

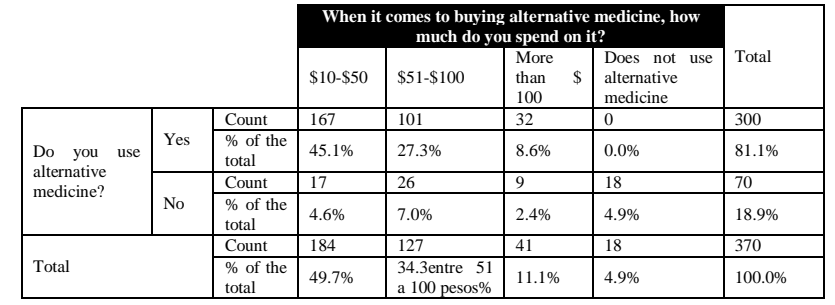

Table 9 Relationship of use of Alternative Medicine with investment in the product. Adapted from SPSS version 22

Note: This is an interesting fact, because, although people consume Alternative Medicine, their investment does not exceed $\$ 100.00$, since $45.1 \%$ spend between 10 to 50 pesos, and $27.3 \%$ spend between 51 to 100 pesos, so that the Pricing strategies should consider what consumers prefer to spend and / or use trust to persuade the consumer to increase this investment.

\section{Discussion}

The results obtained with respect to the age range, which mainly range between 18 and 27 years $(39.7 \%)$, the most predominant academic level is secondary school $(39.7 \%)$ and the activity they mainly perform is a trade $(49.5 \%)$, which were obtained in this research, are consistent with those found in the publication by Rocío Santiváñez (2020), Use of alternative and complementary medicine therapies in the province of Coronel Portillo, Ucayali, Peru, in which it turned out that the majority of those surveyed were women $(68.3 \%)$, primarily in the 18 to 30 age range $(29.2 \%)$, as well as having an independent occupation with $38.1 \%$, although in the latter they are dedicated to their home with $38.6 \%$.
Similarly, in the study Use of health facilities of the Ministry Of Health of Peru, 2009-2011 (Curioso, Pardo, and Valeriano, 2013) it emerged that it is the female sex with $55.4 \%$ who most use alternative medicine, as well as aged up to 29 years with $48.5 \%$. What gives a guideline for marketing strategies (product and communication) to be directed mainly to this sex and especially to young people and adults.

According to Peña and Paco (2007) in the Alternative Medicine research: attempted analysis, they mention that visits to establishments of these products have increased, as well as that in some countries such as Chile, Colombia, Ethiopia and Lima consumption is of $70 \%, 40 \%, 90 \%$ and $57 \%$ respectively, which corresponds to the findings of $81.1 \%$ of this research, that if they use Alternative Medicine in the Municipal Head of Villa Guerrero, as well as that they go to health food stores with a $40.3 \%$. Therefore, the following marketing strategies are considered as a proposal for the establishments of health food stores ("Don Miguel", in Plaza San José Villa Guerrero, "Mixteco Botanical Center", José María García street, "Centro Naturista Torres", calle Heroes of September 14) of the Municipal Head of Villa Guerrero, State of Mexico:

1. Product Strategies: Objective, to generate greater interaction with customers to position it in the consumer's mind as a reliable and quality product. Exhibitions and setting (Technique: establishment of a tent for the exhibition and setting related to Alternative Medicine in the center of Villa Guerrero. Tactic: carry it out every 2 months so that people know alternative medicine, as well as its benefits and diseases it can treat); Demonstrations (Use a stand in the center, in the civic square, as well as outside the Bicentennial General Hospital, where there is more traffic of people. Tactic: do it every month so that people know the presentations of the product that Alternative Medicine handles). 
2. Price Strategies: Objective, increase the sales volume of natural products and motivate the desire to buy. Psychological price (Technique: Set prices ending at \$ 0.99 in the line of herbalists and ointments, so that an impact is generated in the consumer's mind. Tactic: place the ointments and herbalists in an attractive display by setting the prices in the central part of the product, for a month); Price setting based on competition (Technique: Set the price according to the price that scientific medicine manages, mainly in those that treat respiratory and digestive discomforts. Tactic: Apply a price equal to that used in pharmacies for pills that relieve respiratory discomfort and stomach, highlighting the benefits).

3. Distribution Strategies: Objective, to distribute the products in the most recurring points, in addition to facilitating the purchase using digital media. Selective distribution (Technique: The products will be taken to Supermarkets, health food stores in another nearby town. Tactic: Send Alternative Medicine products using a short distribution channel); Positioning by online point of sale (Technique: Consumers will have access to a web page to search for the product, prices, benefits, discomforts, among other characteristics. Tactic: The web page could be promoted on different social networks such as WhatsApp, Facebook and Instagram, so that they can place their order).

4. Communication Strategies: Objective, Inform the benefits of Alternative Medicine for health, strengthening people in their lifestyles, for the prevention, correction and support of diseases. Traditional advertising (Technique: through brochures and triptychs the benefits of the different products will be announced, with respect to the diseases they contribute. Tactic: they will be distributed to passers-by who pass through the streets where the establishments are located so that they know the benefits of the Alternative Medicine offered, as well as location and contact information).

\section{Conclusions}

Consequently, derived from the results of the research carried out, it can be concluded that marketing is a science that can be applied to large, medium, small or micro-businesses, regardless of the type of business they offer. And to the bewilderment of many, perhaps, applying marketing to Alternative Medicine establishments is not so usual, because there is still controversy in its acceptance, verification and legislation in various countries, and Mexico is no exception.

However, it has also been reviewed that Alternative Medicine is a cultural tradition that has had advances in medical sciences, which have increasingly increased its use as complementary treatments to various diseases, therefore its use and sale is increasing.

Therefore, it is convenient to help in economic development through strategies that help position the products that are offered in the market, resulting in the same ones that were already described in the previous section in a generic way.

Therefore, perhaps it is others who can delve into the investigation, by viewing administratively and commercially these types of establishments as businesses, and not as invaders of society, due to the fact that it is the population who has had confidence in the products, in its use and application periodically for various diseases such as respiratory, digestive, nervous or others that may suffer.

Finally, the investigation remains open to seek strategies that can diversify the variety of products, as well as their presentation and distribution, in addition to changing their image, to gain customer loyalty and the prestige of brands, in the Alternative Medicine framework. 


\section{References}

Berenzon Gorn, S., Alanís Navarro, S., y Saavedra Solano, N. (2009). El uso de las terapias alternativas y complementarias en población mexicana con trastornos depresivos y de ansiedad: resultados de una encuesta en la Ciudad de México. Salud mental, 32(2), 107115. Recuperado el noviembre de 2020, de http://www.scielo.org.mx/scielo.php?script=sci _arttext\&pid=S0185-

33252009000200003\&lng=es\&tlng=es.

Bernal, C. (2010). Metodología de la Investigación. Colombia: Pearson Educación.

Blanco Guarin, R. E. (2017). Medicinas alternativas: perpetuación de la ignorancia o utilización de información histórica. (Salud, Ed.) Revista de la Universidad Industrial de Santander., 49(3), 416-418, ISSN: 0121-0. Recuperado el 19 de enero de 2020, de https://www.redalyc.org/articulo.oa?id=3438/3 43855203001

Canal Once. (11 de agosto de 2014). Documental: Medicina tradicional, dosis de salud e identidad. (Archivo de Vídeo). Youtube. Obtenido de https://www.youtube.com/watch?v=lWXA_hF $\mathrm{MGa} 4$

Curioso, W. H., Pardo, K., y Valeriano, L. (2013). Use of health facilities of the Ministry Of Health of Peru, 2009-2011. Revista Peruana de Medicina Experimental y Salud Pública, 30(2), 175-180. Obtenido de http://www.scielo.org.pe/scielo.php?script=sci_ arttext\&pid=S1726-

$46342013000200003 \& \operatorname{lng}=e s \& t \operatorname{lng}=e n$.

Díaz, M. (2013). Perspectivas de las medicinas alternativas $\mathrm{y} / \mathrm{o}$ complementarias en la Universidad del Valle de Atemajac (UNIVA), Campus Zapopan, Jalisco. Universidad del Valle de Atemajac, 93-101. Recuperado el noviembre de 2020, de http://biblioteca.univa.mx/Anuario/2013/2013_ 4_perspectiva.pdf
Dirección General de Planeación y Desarrollo en Salud. (2013). Dirección de Medicina Tradicional y Desarrollo Intercultural. Obtenido de Dirección General de Planeación y Desarrollo en Salud: http://www.dgplades.salud.gob.mx/interior/dmt di.html

Enciclopedia económica. (2018). Obtenido de Mercadotecnia:

https://enciclopediaeconomica.com/mercadotec nia/

Ferrell, O., y Hartline, M. (2012). Estrategia de Marketing. México: Cengage Learning.

Galeano, S. (mayo de 2019). Obtenido de Estrategias de Marketing: definición y claves: https://marketing4ecommerce.mx/estrategiasde-marketing-definicion/

Gallegos-Zurita, M., y Gallegos-Z, D. (2017). Plantas medicinales utilizadas en el tratamiento de enfermedades de la piel en comunidades rurales de la provincia de Los Ríos Ecuador. Anales de la Facultad de Medicina, 78(3), 315321. Obtenido de https://dx.doi.org/10.15381/anales.v78i3.13767

Hernández, R., Fernández, C., y Baptista, M. (2010). Metodología de la Investigación. México: Mc Graw Hill.

Martínez, A., Ruiz, C., y Escriva, J. (2014). Marketing en la actividad comercial. España: Mc Graw Hill. Obtenido de https://www.mheducation.es/bcv/guide/capitulo /844819358X.pdf

MedlinePlus. (2020). Medicina alternativa para el alivio del dolor. Obtenido de Biblioteca Nacional de Medicina de los EE.UU.: https://medlineplus.gov/spanish/ency/article/00 2064.htm

Peña, A., y Paco, O. (2007). Medicina alternativa: intento de análisis. . Anales de la Facultad de Medicina, 68(1), 87-96. Obtenido de http://www.scielo.org.pe/scielo.php?script=sci arttext\&pid=S1025-

$55832007000100012 \& \operatorname{lng}=$ es\&tng=es. 
Pinedo, A. (2018). Estrategias de marketing para el consumo de productos de medicina natural, Iquitos. Iquitos, Perú: Tesis de Doctorado. Facultad de Ciencias Económicas y de Negocios.

Ramírez, M. (06 de junio de 2018). Cofepris le da su lugar a la herbolaria mexicana. Obtenido de El Economista: https://www.eleconomista.com.mx/opinion/Cof epris-le-da-su-lugar-a-la-herbolaria-mexicana20180606-0026.html

Rattinger, Á. (octubre de 2018). Qué es mercadotecnia y por qué es importante. Obtenido de Merca 2.0: https://www.merca20.com/que-es-

mercadotecnia-definicion/

Rodríguez, J. (1998). Medicina Alternativa en el currículo médico. México: Facultad de medicina de la UNAM. Recuperado el noviembre de 2020, de

http://www.facmed.unam.mx/_gaceta/gaceta/oc t1098/ALTERNA.html

Romero, B. (22 de octubre de 2019). Obtenido de Qué es el Marketing Mix: Las 4P's del Marketing: https://www.begoromero.com/quees-marketing-

mix/\#: :text=El $\% 20$ marketing $\% 20 \mathrm{mix} \% 20 \mathrm{se} \%$ 20define,llaman\%20las\%204P's\%20por\%20su Sangri, A. (2014). Introducción a la mercadotecnia. México: Patria.

Santana, B., García, M., Millán, M., y Miranda, D. (marzo de 2020). Estrategias de Mercadotecnia para impulsar el consumo de Medicina Alternativa en la Cabecera Municipal de Villa Guerrero, Estado de México. Tesis de Licenciatura. México: Tecnológico de Estudios Superiores de Villa Guerrero.

Santiváñez-Acosta, R., Valenzuela-Oré, F., y Angulo-Bazán, Y. (2020). Uso de terapias de medicina alternativa y complementaria en la provincia de Coronel Portillo, Ucali, Perú. Rev Peru Med Exp Salud Publica, 37(3), 510-515. Obtenido de https://doi.org/10.17843/rpmesp.2020.373.4939

SENA. (noviembre de 2006). Caracterización Ocupacional del área de Medicina Alternativa y Terapias Complementarias. Bogotá, Colombia: Servicio Nacional de Aprendizaje.
Zhang, X. (26 de marzo de 2019). Medicina tradicional: definiciones. Obtenido de OMS: https://www.who.int/topics/traditional_medicin e/definitions/es/ $2 / 3$ 